\title{
Seroprevalence and Risk Factors of Bovine Viral Diarrhea in Improved Cattle of Chitwan, Nawalpur and Rupandehi Districts of Nepal
}

\author{
A. Thapa ${ }^{1}$, M. P. Acharya ${ }^{2}$, R. Raut ${ }^{* 3}$ and S. Rimal ${ }^{1}$ \\ ${ }^{1}$ Institute of Agriculture and Animal Science, Tribhuvan University (TU), Rupandehi, Nepal \\ ${ }^{2}$ National Cattle Research Program, Chitwan \\ ${ }^{3}$ Department of Theriogenology, Agriculture and Forestry University, Rampur, Chitwan, Nepal \\ *Corresponding author: drrobinnpl@gmail.com
}

\begin{abstract}
This study was aimed at assessing the prevalence of bovine viral diarrhea (BVD) in improved dairy cattle of Chitwan, Nawalpur and Rupandehi Districts of Nepal. Altogether 92 blood samples were aseptically collected from jugular vein of cattle and transferred to clot activator tube and transported to National Cattle Research Program, Rampur, Chitwan. This cross sectional study was carried out from Mangsir to Magh of 2075 B.S using purposive sampling Serum separation was done by centrifugation@3500 for 5 minutes. The serum was stored at $20^{\circ} \mathrm{C}$ till ELISA test was done. Serological analysis was done according to the protocol of ID. vet BVD Ab ELISA kit. Data were analyzed using Ms excel and SPSS version 20.0.The seroprevalence of BVD Virus was found to be $7.76 \%$. Provided that no history of vaccination against BVD in cattle was done in the study area, seropositive was due to natural infection. Geographic location as well as sampling method might have contributed to this result. The result indicated lower prevalence along with no statistical significance to breed and age risk factors undertaken during the research. However significant association was observed between abortion history and seropositivity. Hence, there is a need of further research to identify the disease burden and its impact in the agricultural gross domestic products (AGDP).
\end{abstract}

Keywords: Bovine viral diarrhoea, Seroprevalence, ELISA, Dairy cattle

\section{INTRODUCTION}

Bovine viral diarrhea (BVD) is an infectious and highly contagious viral disease of cattle. It is cosmopolitan in distribution and Office International des Epizooitic (OIE) has listed it as notifiable disease. In Nepal, infertility problem in crossbreed and exotic cattle has been reported to be the most prioritized problem in pocket area in the country (Jha, 2000). It is caused by Pestivirus of family Flaviviridae which is characterized by alimentary, respiratory and reproductive disorder along with haemorrahagic syndrome and thrombocytopaenia (Baker, 1995). BVD virus (BVDV) is divided into two biotypes cytopathic (CP) and non-cytopathic (NCP) based on cytopathic effect on cell culture (Vanroose et al., 1998). NCP can cross the placenta and is thus considered important. Noncytopathic crosses through the placenta to establish a persistent infection (PI). If the fetus is infected and survives after birth, BVD virus can severely affect the reproductive and nervous system (Saliki JT 2004). Reproductive problems like abortion and infertility are of major concerns in the dairy farming of Nepal. Very limited information is available regarding the causes of bovine reproductive problems in Nepal. 
The prevalence of persistent BVDV infection in dairy cattle in two commercially important livestock districts i.e. Chitwan was $0.7 \%$ and Kavrepalanchowk was $3.4 \%$ as individual animal prevalence (Gaire T.N et.al., 2016). Import of most of the BVDV infected cross-breed dairy cattle from India makes Tarai of Nepal more susceptible to BVDV. The BVDV is transmitted by direct contact to animals, by transplacental route, by discharges from reproductive tract of an infected cow (Meyling et.al., 1990). The prevalence of persistent BVDV infections ranges from $0.5-2 \%$ in cattle populations from different countries of the world (Charleston B et.al., 2001). In India, $15.3 \%$ cattle and $23.2 \%$ buffaloes were reported to be BVDV positive (Sudharshana K.J. et.al., 1999).

\section{MATERIALS AND METHODS}

The study was carried out from December 2018 to February 2019 at National Cattle Research Program, Rampur, Chitwan. The 92 cattle serum samples were collected from eastern areas of Chitwan (Ratnanagar municipality), Nawalpur (Gaidakot and Kawasoti Municipality) and Rupandehi (Sunwaland Devdaha municipality). Animals were selected on the basis of the history in relation to their reproductive problems. The test was carried out in accordance to the manual of the ID Vet France @ BVD Ab ELISA for in vitro detection of antibodies. The ELISA used was of ID Vet-BVD P80 Antibody detection Lot/Ch.B: 693-008. The sample size necessary for detection of BVDV was calculated from EpiTools Epidemiological Calculators by Ausvet, in assumption of overall $2.2 \%$ of prevalence of BVDV infection in dairy cattle of Nepal (Manandhar S et.al., 2018) computed with expected precision of $5 \%$ and $95 \%$ of confidence level. The data generated were stored in the MS excel 2010 and overall prevalence was calculated from MS excel. Questionnaire survey was also employed that included general description, herd history and individual animal history. Association between the categorical variables and outcomes variable was assessed by using IBM SPSS statistics 20 .

\section{RESULT AND DISCUSSION}

\section{Overall Seroprevalence of BVD}

The study reveals overall seroprevalence of $7.76 \%$ from 92 samples tested, 7 samples being positive. Also, there is no any practice of vaccination against BVD in Nepal, the seropositivity must be attributed in response to natural infections. The samples detected positive by ELISA can be subjected to total RNA extraction and PCR amplified gene of BVDV for further confirmation with greater accuracy.Lower prevalence than this study was reported by Manandhar S (2018) in western Chitwan of Nepal (2.2\%). This study is lower than the prevalence found $13.20 \%$ in Tamil, Nadu (Krishna K.S. et.al., 2017). In contrast to this study, higher seroprevalence were found in different areas like in Europe, comprising more than around 50\% of the isolates in North American 90\% of the isolates (Ridpath J.F., 2005), 51.1\% in Bangladesh (Uddin MA et. al., 2017), 33.2\% in cattle of Selangor, Malaysia (Daves L. et.al., 2016), 15.29\% in cattle of 16 states of India (Sudharshana K. J. et.al., 1999). The higher seroprevalence in other countries might be due to vaccination against BVD. 
Table 1: Seroprevalence of BVD determined by using ID.vet, France Ab ELISA

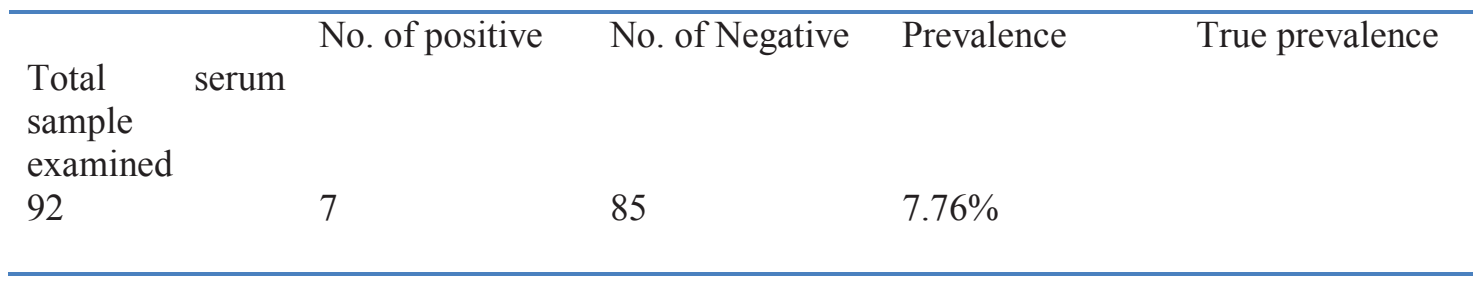

There is no significant association between districts and occurance of BVDV ( $>00.05)$. But Chitwan (9.37\%) and Nawalpur (12.9\%) have more prevalence percent than Rupandehi (0\%). This might be affected by geographical location, sampling method and management practices. Sampling technique may have major role in missing out the positive samples.

Table 2: Districtwise seroprevalence of BVD

\begin{tabular}{|l|l|l|l|l|l|}
\hline Districts & Total tested & Positive & Negative & Prevalence \% & P-value \\
\hline Chitwan & 32 & 3 & 29 & 9.37 & 0.152 \\
\hline Nawalpur & 31 & 4 & 27 & 12.90 & \\
\hline Rupandehi & 29 & 0 & 29 & 0 & \\
\hline
\end{tabular}

The study found no significant difference $(\mathrm{p}>0.05)$ between age and prevalence. Statistically it is not significant which indicates that both age groups have equal probability of getting BVD. This result is in contrast with Daves L. et.al., 2016 whose finding shows that the prevalence positivity increases with age.

Table 3: Age wise Seroprevalence of BVD

\begin{tabular}{|l|l|l|l|l|l|}
\hline Age & Positive & Negative & Total & Prevalence & P-value \\
\hline 3 and less (young) & 4 & 45 & 49 & 8.16 & 0.830 \\
\hline 4 and more (adult) & 3 & 40 & 43 & 6.97 & \\
\hline
\end{tabular}

There is no significant difference $(\mathrm{P}>0.05)$ between breed and prevalence. The present study indicates prevalence percent higher in Holstein, statistically it is not significant indicating that both breeds have equal chance to be infected with BVD. The prevalence percent was higher in Jersey cross $(7.76 \%)$ than Holstein-Friesian cross $(0 \%)$. This might be due to the higher number of Jersey crosses in tested sample.

The result is in agreement with S. Manandhar (2018) findings which shows prevalence of Jersey cross $(2.4 \%)$ than Holstein-Friesian (1.7\%) and with (Daves L. et.al., 2016) which shows that higher prevalence is in Jersey breed of cattle than Holstein Friesian. 
Table 4: Breed wise prevalence of BVDV

\begin{tabular}{|l|l|l|l|l|l|}
\hline Breed & Positive & Negative & Total & Prevalence \% & P-value \\
\hline Jersey cross & 7 & 65 & 72 & $9.72 \%$ & 0.147 \\
\hline Holstein cross & 0 & 20 & 20 & $0 \%$ & \\
\hline
\end{tabular}

\section{Seroprevalence of BVDV with Abortion History}

Seroprevalence of BVD between abortion history and result was found to be significant $(\mathrm{P}=0.015$, i.e. $\mathrm{P}<0.05)$ Odd Ratio: 6.333, The chance of $\mathrm{BVD}$ with history of abortion is 6.333 times more than the no history of abortion. This results is in agreement with S.Y. Derdour 2017 which findings shows that there was significant association between abortion and seropositivity $(\mathrm{OR}=14.21)$.

Table 5: Abortion history wise seroprevalence

\begin{tabular}{|l|l|l|l|l|l|}
\hline $\begin{array}{l}\text { Abortion } \\
\text { history }\end{array}$ & Positive & Negative & Total tested & Prevalence & P-value \\
\hline Yes & 3 & 9 & 12 & $25 \%$ & 0.015 \\
\hline No & 4 & 38 & 42 & $9.523 \%$ & \\
\hline
\end{tabular}

\section{CONCLUSION}

The result of the present study suggests that our dairy cattle have been infected with BVDV. This study found no significant association between seropositivity with district, age and breed with pvalue $0.152,0.830$ and 0.147 respectively. However significant association was observed between abortion and seropositivity with p-value 0.015 and Odd ratio 6.333. Different tools like systematic control, culling PI animas, restriction of movement of infected herds should be used to contain this disease. There is a need of further research in molecular level to better understand the different factors causing the BVD.

\section{ACKNOWLEDGEMENT}

The authors are thankful to all the supporting staffs of National Cattle Research Program, Rampur, Chitwan for their help and cooperation during the study. We are grateful to the Institute of Agriculture and Animal Science for providing financial support for conducting this research. 


\section{REFERENCES}

Baker, J.C. (1995). The clinical manifestations of bovine viral diarrhea infection. Veterinary Clinics: Food Animal Practice, 11: 425-445. doi.org/10.1016/S0749-0720 (15)30460-6

Charleston, B., Fray, M.D., Baigent, S., Carr, B.V. and Morrison, W.I. (2001). Establishment of persistent infection with non-cytopathic bovine viral diarrhea virus in cattle is associated with a failure to induce type I interferon. J. Gen. Virol, 82:1893-1897. doi.org/10.1099/0022-1317-82-8-1893

Daves, L., Yimer, N., Arshad, S.S., Sarsaifi, K., Omar, M.A., Yusoff, R., Haron, A.W. and Abdullah, F.F. (2016). Seroprevalence of Bovine Viral Diarrhoea Virus Infection and Associated Risk Factors in Cattle in Selangor, Malaysia. Vet. Med, 1:2228.doi.org/10.17140/VMOJ-1-105

Derdour, S.Y., Hafsi, F., Azzag, N., Tennah, S., Laamari, A., China, B. and Ghalmi, F. (2017) Prevalence of the main infectious causes of abortion in dairy cattle in Algeria. $J$ Vet Res, 61:337-343doi.org/10.1515/jvetres-2017-0044

Gaire, T. N., Karki, S., Karna, A. K., Khanal, D. R., Steneroden, K., Poudel, K. and Bowen, R. A. (2016). Prevalence of Bovine Viral Diarrhea Virus Infection in Dairy Herds of Nepal. Asian Journal of Animal and Veterinary Advances, 11:434-440. DOI: 10.3923/ajava.2016.434.440

Jha, V.C. (2000) Study on infectious causes of infertility in crossbred and exotic cattle in Nepal. Annual Report (1999/2000), Animal Health Research Division, Tripureshwor, pp19-23

Krishna, K.S., Palanivel, K.M., Sukumar, K., Masilamoni Ronald, S.B., Selvaraju, G. and Ponnudural, G. (2017). Herd-level risk factors for bovine viral diarrhoea infection in cattle of Tamil Nadu. Trop Anim Health prod, 50:793-799. doi.org/10.1007/s11250-017-1497-z

Manandhar, S., Yadav, G.P. and Singh, D.K. (2018). Epidemiological survey of bovine viral diarrhea in dairy cattle in Nepal. OIE bulletin newsfeed. DOI: 10.20506/bull.2018.NF.2860

Meyling, A., Houe, H. and Jensen, A. M. (1990). Epidemiology of bovine virus diarrhoea virus. Rev Sci Tech, 9:75-93. doi.org/10.20506/rst.9.1.489

Ridpath, J.F. (2005). Practical significance of heterogeneity among BVDV strains: impact of biotype and genotype on US control programmes. Prev. Vet. Med,72:17-30. doi:10.1016/j. pre vet med.2005.08.003.

Saliki, J.T. and Dubovi, E.J. (2004). Laboratory diagnosis of bovine viral diarrhea Virus infections. Veterinary Clinics of North America: Food Animal Practice, 20:73-75. doi.org/10.1016/j.cvfa.2003.11.005

Sudharshana, K. J., Suresh, K. B., and Rajasekhar, M. (1999). Prevalence of bovine viral diarrhea virus antibodies in India. Revue scientifique et technique-Office international des épizooties, 18:667-671. doi.org/10.20506/rst.18.3.1189

Uddin, M.A., Ahasan, A.S.M.L., Islam, K., Islam, M.Z., Mahmood, A., Islam, A., Islam. K.M.F. and Ahad, A. (2017).Seroprevalence of bovine viral diarrhea virus in crossbred dairy cattle in Bangladesh. Veterinary world. 10:906-913. DOI: 10.14202/vetworld.2017.906-913

Vanroose, G., Nauwynck, H., Soom, A. V., Vanopdenbosch, E. and Kruif, A. D. (1998). Replication of Cytopathic and Noncytopathic Bovine Viral Diarrhea Virus in Zona-Free and Zona-Intact In Vitro-Produced Bovine Embryos and the Effect on Embryo Quality. Biology of reproduction, 58:857-866. doi.org/10.1095/biolreprod58.3.857 